\title{
Campur Kode dalam Rublik Opini Koran Radar Banten Edisi November-Desember 2016
}

\author{
Febri Sukma Afriyanti ${ }^{1}$, Ira Anisa Purawinangun ${ }^{2}$ \\ Universitas Muhammadiyah Tangerang \\ Febrysukma23@gmail.com
}

\begin{abstract}
Abstrak
Seseorang yang menguasai bahasa lebih dari satu memungkinkan terjadinya campur kode saat penutur dan mitratutur berbicara. Campur kode tersebut terjadi apabila dalam suatu tuturan terdapat unsur bahasa yang berbeda dengan bahasa yang sedang digunakan. Hal tersebut melatarbelakangi penulis untuk menganalisis campur kode yang terdapat dalam rubrik opini koran Radar Banten edisi November-Desember 2016. Adapun tujuan dari penelitian ini adalah untuk mengetahui dan mendeskripsikan bentuk campur kode yang terdapat dalam rubrik opini koran Radar Banten edisi November-Desember 2016. Penelitian ini merupakan penelitian kualitatif dengan menggunakan metode deskriptif kualitatif, yaitu metode yang bertujuan membuat deskripsi, gambaran secara sistematis, faktual dan akurat mengenai data. Penelitian ini menggunakan tekhnik analisis isi atau content analysis. Berdasarkan hasil analisis data, penelitian ini menghasilkan temuan campur kode dalam rubrik opini koran Radar Banten edisi November-Desember 2016. Adapun temuan campur kode tersebut adalah sebagai berikut : (1) campur kode berbentuk kata sebanyak 31 data; (2) campur kode berbentuk frase sebanyak 12 data; (3) campur kode berbentuk baster sebanyak 3 data; (4) campur kode berbentuk klausa sebanyak 2 data; (5) campur kode berbentuk ungkapan sebanyak 1 data. Jumlah data keseluruhan dari hasil penelitian ini berjumlah 49 data, yang terdiri dari campur kode dengan bahasa Inggris, campur kode dengan bahasa Arab, campur kode dengan bahasa Jawa, dan campur kode dengan bahasa Betawi. Secara keseluruhan, campur kode bahasa Inggris ke dalam bahasa Indonesia lebih dominan dibandingkan dengan campur kode bahasa Arab, campur kode bahasa betawi, dan campur kode bahasa Jawa.
\end{abstract}

Kata Kunci : Campur kode, rublik, opini, koran

\section{A. Pendahuluan}

Di dalam kehidupan sehari-hari, manusia tidak akan pernah terlepas dari bahasa sebagai alat komunikasi untuk berinteraksi dengan orang lain. Interaksi tersebut akan terjalin dengan baik apabila bahasa yang digunakan oleh penutur dapat dimengerti oleh mitratutur. Saat terjadi percakapan, sering kali kita mendengar seseorang menyisipkan unsur bahasa yang berbeda 
dengan bahasa yang sedang digunakan. Misalnya, dalam percakapan dengan bahasa Indonesia kemudian dalam percakapan tersebut terdapat unsur bahasa sunda. Disitulah terjadi proses campur kode. Dikatakan campur kode karena terdapat sisipan bahasa sunda di dalam percakapan bahasa Indonesia.

Saat manusia berinteraksi dengan manusia lainnya dalam keadaan tertentu, akan didapati manusia yang mampu berbicara lebih dari satu bahasa, bahkan ada yang menguasai lebih dari dua bahasa. Di Indonesia pada umumnya masyarakat menggunakan bahasa Indonesia sebagai bahasa keduanya dan menggunakan bahasa daerah sebagai bahasa pertamanya, banyak juga masyarakat yang menggunakan beberapa bahasa, baik menggunakan bahasa Indonesia, bahasa daerah dan juga bahasa asing lainnya.

Faktor masyarakat bilingual atau bahkan multilingual bisa disebabkan oleh beberapa faktor. Misalnya perkawinan, anak-anak yang berasal dari perkawinan campur beda bangsa dan bahasa sangat mungkin mampu memahami dan menggunakan beberapa bahasa yang berbeda. Faktor imigrasi, yaitu perpindahan penduduk yang menyebabkan keanekabahasaan, sesorang yang berimigrasi ke daerah atau negara lain tentu saja menyebabkan bahasa ibu mereka tidak berfungsi di daerah baru. Ada pula faktor pendidikan. Sekolah biasanya mengajarkan bahasa asing kepada anak-anak yang menyebabkan si anak menjadi bilingual atau bahkan multilingual, misalnya anak-anak yang belajar di pesantren diwajibkan berbahasa pengantar bahasa Inggris bahkan bahasa Arab sehingga sangat mungkin si anak menguasai beberapa bahasa asing. Bahkan orang yang belajar di luar negeri harus mampu menyesuaikan diri dengan bahasa tertentu tempat ia menuntut ilmu, orang demikian menjadi bilingual atau multilingual.

Masyarakat di Indonesia umumnya menguasai dua bahasa yaitu bahasa daerah dan bahasa Indonesia, bahkan banyak pula yang menguasai lebih dari dua bahasa atau multilingualisme. Kemampuan masyarakat menggunakan dua bahasa atau lebih memungkinkan terjadinya peristiwa campur kode yang pada umumnya peristiwa campur kode tersebut terjadi secara tidak sengaja dengan adanya sisipan dari bahasa yang dikuasai.

Faktor penyebab campur kode umumnya apabila seorang penutur menggunakan suatu bahasa secara dominan untuk mendukung suatu tuturan yang disisipi dengan unsur bahasa lainnya. Gejala campur kode ini biasanya terkait dengan karakteristik penutur. Misalnya, latar belakang sosial, pendidikan dan kepercayaan. Peristiwa campur kode bisa juga terjadi karena faktor kebiasaan akibat dari pergaulan antara penutur bahasa. Campur kode terjadi karena faktor 
keinginan menjelaskan dan menafsirkan sesuatu yang disebabkan oleh keinginan si penulis untuk menyampaikan tulisannya agar dapat dipahami oleh pembaca dengan baik. Peristiwa campur kode yang biasa terjadi dalam komunikasi percakapan lisan, juga dapat terjadi pada percakapan tulisan atau bahasa lisan yang dituliskan. Salah satunya dalam media cetak seperti surat kabar.

Pemilihan penelitian mengenai gejala kebahasaan berupa campur kode yang dipilih penulis dalam koran Radar Banten rubrik opini, karena gejala kebahasaan ini sering sekali terjadi baik dalam tutur kata maupun tulisan seseorang. Hal ini terjadi karena arus globalisasi yang pesat dan menuntut seseorang untuk dapat menyerap informasi sebanyak mungkin dengan menguasai bahasa ibu dan bahasa kedua. Seperti halnya para penulis dalam rubrik opini ini yang menyerap dan menggunakan bahasa daerah atau bahasa asing dalam tulisannya. Namun, sikap yang lebih mengedepankan kosa kata asing merupakan sikap yang tidak sesuai dengan semangat berbahasa Indonesia. Oleh karena itu, fenomena kebahasaan ini tentu saja menarik untuk diteliti karena dapat menambah wawasan keilmuan linguistik khususnya bidang sosiolinguistik.

Koran Radar Banten merupakan koran daerah yang sangat menarik minat peneliti untuk menganalisis campur kode dalam koran tersebut, yaitu campur kode dalam rubrik opini, baik unsur yang berwujud kata, frasa, klausa, baster, maupun ungkapan. Berdasarkan latar belakang masalah tersebut, peneliti tertarik untuk melakukan penelitian ini dengan judul " Campur Kode Dalam Rubrik Opini Koran Radar Banten Edisi November-Desember 2016 “. Tujuan penelitian yang akan dicapai dalam penelitian ini untuk mengetahui dan mendeskripsikan bentuk campur kode yang terdapat dalam rubrik opini koran Radar Banten edisi November-Desember 2016.

\section{B. Kajian Pustaka}

Setelah sebuah kalimat lahir dan didengar oleh individu lain, lalu individu tersebut akan melakukan pekerjaan yang diminta. Kesediaan seorang individu dalam melakukan pekerjaan itu tentu karena adanya kerja sama antarindividu. Oleh karena itu, dapat dikatakan bahwa bahasa bersifat kooperatif. Di samping bahasa bersifat kooperatif, bahasa juga digunakan sebagai alat komunikasi. Menurut Aslinda dan Syafyahya (2014) penggunaan bahasa sebagai alat komunikasi dipengaruhi oleh banyak faktor. Antara lain adalah faktor sosial dan faktor situasional (h.2).

Menurut Aslinda dan Syafyahya (2010), "Campur kode terjadi apabila seorang penutur bahasa, misalnya bahasa Indonesia memasukkan unsur-unsur bahasa daerahnya ke dalam pembicaraan bahasa Indonesia" (h.87). Dengan kata lain, seseorang yang berbicara dengan kode utama bahasa Indonesia yang memiliki fungsi keotomoniannya, sedangkan kode bahasa daerah 
yang terlibat dalam kode utama merupakan serpihan-serpihan saja tanpa fungsi atau keotomonian sebagai sebuah kode.

Faktor penyebab campur kode merujuk pada pendapat Suwito (1983), dikategorikan menjadi dua tipe, yaitu tipe berlatar sikap (attitudinal type) dan tipe berlatar kebahasaan (linguistic type) (h.77).

\section{Faktor Sikap (attitudinal type)}

a) Adanya kebutuhan, maksudnya penutur mengunakan bahasa lain untuk lebih memperluas maksud tuturan.

b) Adanya faktor sosial, yaitu penutur pengaja mengambil kata dari bahasa lain dengan mempertimbangkan faktor sosial. Dalam hal ini, penutur cenderung bercampur kode dengan bahasa yang dianggap lebih mencerminkan status sosialnya.

\section{Faktor Kebahasaan (linguistic type)}

Seseorang melakukan campur kode juga disebabkan oleh faktor kebahasaan. Antara lain:

a) Karena kata-kata dalam bahasa lain tersebut lebih mudah diingat;

b) Keterbatasan kata-kata dalam bahasa yang digunakan oleh penutur (misalnya, banyaknya istilah dalam bidang telkomunikasi menyebabkan penutur sulit menemukan kata dalam bahasa Indonesia yang merujuk pada kata-kata seperti flasdisk, install, dan restart.

Dari beberapa pendapat tersebut, dapat disimpulkan bahwa pada fenomena campur kode adalah seorang penutur pada dasarnya menggunakan sebuah varian suatu bahasa. Pada penggunaan itu, dia menggunakan serpihan-serpihan kode dari bahasa yang lain. Serpihanserpihan unsur bahasa tersebut dapat berupa kata sampai klausa, dapat juga berupa kata ulang, idiom maupun baster.

Menurut Aslinda dan Syafyahya (2004) Ciri-ciri yang menonjol dalam campur kode adalah kesantaian atau situasi informal. Dalam situasi berbahasa formal jarang terjadi campur kode, kalau terdapat campur kode dalam keadaan itu karena tidak ada kata atau ungkapan yang tepat untuk menggantikan bahasa yang sedang dipakai sehingga perlu memakai kata atau ungkapan dari bahasa daerah atau bahasa asing (h.87). 
Campur kode merupakan fenomena yang terjadi karena masuknya serpihan unsur suatu bahasa ke dalam bahasa yang lain. Hal ini tidak berarti bahwa tidak ada sebab terjadinya campur kode. Ada kemungkinan campur kode terjadi karena faktor individu, seperti ingin menunjukan status, peran, dan lain sebagainya. Ada juga kemungkinan sebab kurangnya unsur bahasa yang digunakan.

Opini publik adalah pendapat dari sekelompok masyarakat yang merupakan hasil interaksi individu-individu dalam suatu diskusi atau perdebatan berdasarkan suatu masalah tertentu.

\section{a. Karakter Opini Publik}

Redi Panuju (2002), menegaskan pergeseran yang terjadi dalam opini publik disebabkan oleh beberapa faktor, diantaranya :

\section{1) Faktor Psikologis}

Tidak ada kesamaan antara individu yang satu dengan individu yang lainnya, yang ada hanya kemiripan yang memiliki banyak perbedaan. Perbedaan antarindividu yang meliputi hobi, kepentingan, pengalaman, selera, dan kerangka berpikir menjadikan setiap individu berbeda bentuk dan cara merespon stimulus atau rangsangan yang menghampirinya. Perbedaan faktor psikologis menyebabkan pemaknaan terhadap kenyataan yang sama bisa menghasilkan penyandian yang berbeda-beda. Bisa saja output komunikasi tidak sama dengan input komunikasi karena perbedaan beberapa unsur yang bekerja dalam seleksi internal yang meliputi dimensi pemikiran dan dimensi emosi.

2) Faktor Sosiologi Politik

Opini publik terlibat dalam interaksi sosial. Contohnya, opini publik menunjukkan citra seperioritas dan opini publik menunjukkan keikutsertaan individu ke kejadian tertentu, opini publik sesuai dengan kemauan banyak orang dan opini publik identic dengan hegemoni ideologi .

3) Faktor Budaya

Budaya mempunyai pengertian yang beragam. Budaya adalah seperangkat nilai yang digunakan mengelola, memelihara hidupnya, menjaga dari gangguan internal maupun eksternal, dan mengembangkan kehidupan manusia. Nilai-nilai yang 
terhimpun dalam sistem budaya itu oleh individu dijadikan identitas sosialnya atau dijadikan ciri-ciri keanggotaanya di komunitas budaya tertentu.

4) Faktor Media Massa

Menurut Mayer, yang dikutip Redi Panuju, interaksi antara media dan institusi masyarakat menghasilkan produk berupa isi media. Oleh audience, isi media diubah menjadi gugusan-gugusan makna. Apakah yang dihasilkan dari proses penyandian pesan itu, menurut Mayer, sangat ditentukan oleh norma yang berlaku dalam masyarakatnya, pengalaman individu yang lalu, kepribadian individu, dan selektifitas penafsiran (Olii dan Erlita, 2011, h.18-21).

b. Pembentukan Opini

1) Hubungan antara sikap dan opini

Santoso Satropoetro (1990), menyatakan opini adalah pernyataan tentang sikap mengenai masalah tertentu yang bersifat kontroversial. Opini timbul sebagai hasil pembicaraan tantang masalah yang kontroversial yang menimbulkan pendapat berbeda-beda. Lalu, bagaimana dengam sikap? Menurut Cutlip dan Center, sikap (attitude), adalah kecenderungan memberikan respons terhadap masalah atau situasi tertentu (Olii dan Erlita, 2011, h.33).

Opini dan sikap memiliki pengertian yang berbeda. Akan tetapi, kedua istilah itu sama-sama mengacu ke interaksi yang berkesinambungan. Sikap ada di dalam diri seseorang, sedangkan opini keluar dari diri seseorang. Dengan demikian, sikap dan opini mengacu ke kerjasama yang berkesinambungan di dalam siri manusia dalam menghadapi masalah atau situasi tertentu.

Sikap masyarakat diupayakan agar bisa menguntungkan dan mendukung penyebaran opini baru. Sikap yang bertentangan diusahakan dinetralisir ataupun dibelokkan, sehingga opini baru itu menang.

2) Pembentukan opini dan modernisasi

Masyarakat di Negara yang sedang berkembang seperti Indonesia (terutama di daerah-daerah terpencil) sering memiliki tradisi yang buruk. Akibatnya modernisasi lebih sukar diwujudkan.

Komunikator ke arah modernisasi memiliki kecakapan mengidentifikasi kemungkinan penolakan yang disebabkan oleh sikap yang dialaminya. 
Kominikator harus menyelidiki dan mengetahui sikap kelompok. Komunikator harus menggunakan sikap masyarakat yang mendukung opini baru. Komunikator harus bertindak dengan teknik persuasip.

Banyak komunikasi dan penyeberan opini yang di lakukan pihak swasta maupun pemerintah mengalami kegagalan karena mengandalkan persuasi yang sekadar sebagai pemberian data. Stimuli yang diterima masyarakat bermanfaat untuk mencari pemecahan masalah. Komunikator menggunakan pengetahuannya untuk memberikan stimuli kepada masyarakat. Jelas, pemecahan persoalan dapat dilakukan dengan komunikasi yang serasi. Kedudukan ilmu komunikasi ada di antara sosiologi dan psikologi sosial. Ilmu komunikasi menyelidiki dan memengaruhi keadaan masyarakatnya.

\section{Metode Penelitian}

Pendekatan yang diterapkan dalam penelitian ini adalah penelitian kualitatif dengan menggunakan metode analisis isi (content analysis). Penelitian kualitatif sifatnya deskriptif analisis, yaitu data yang diperoleh dari observasi, analisis dokumen dan lain-lain, yang disusun peneliti di tempat penelitian, dan tidak dijabarkan dalam bentuk angka-angka melainkan dalam bentuk kata-kata dan bahasa. Metode kualitatif data yang dikumpulkan berupa kata-kata, gambar dan bukan angka-angka. Selain itu yang dikumpulkan berkemungkinan menjadi kunci terhadap apa yang sudah diteliti. Metode tersebut sesuai dengan tujuan dalam penelitian ini, yaitu untuk mengetahui dan mendeskripsikan wujud campur kode yang terdapat dalam rubrik opini koran Radar Banten edisi November-Desember 2016.

Sumber data penelitian ini diambil dari salah satu kolom yang terdapat di dalam media massa atau surat kabar. Salah satu kolom yang dijadikan bahan penelitian yaitu rubrik opini yang terdapat dalam surat kabar Radar Banten edisi November-Desember 2016. Dalam penelitian ini, pengumpulan data primer dan sekunder dilakukan dengan cara melakukan teknik-teknik kepustakaan melalui buku-buku. Inilah yang berhubungan dengan analisis yang akan dibahas oleh peneliti.

1. Data primer, adalah data utama yang didapatkan secara langsung dalam penelitian ini. Data yang akan diteliti dalam penelitian ini adalah rubrik opini koran Radar Banten edisi November-Desember 2016 
2. Data sekunder, yaitu data yang bukan diperoleh dari sumber utama, karena tidak didapatkan secara langsung, namun sudah tersedia berupa buku-buku referensi yang dijadikan acuan dalam penulisan penelitian ini.

Sosiologi Bahasa, Pengantar Sosiolinguistik, Pedoman Umum Tata Bahasa Indonesia, Inilah Bahasa Indonesia Yang Benar III, Sosiolinguistik Perkenalan Awal, Linguistik Umum, Kamus Linguistik, Metodologi Penelitian Kualitatif, Sosiolinguistik Suatu Pengantar, Opini Publik, Morfologi, Kajian Sosiolinguistik Ihwal Kode dan Alih Kode, Sintaksis, Metodologi Penelitian Pendidikan, Sosiolinguistik, Pengantar Awal Sosiolinguistik Teori dan Problema, Pengajaran Kedwibahasaan.

Teknik pengumpulan data dapat dilakukan dengan berbagai cara, antara lain dengan cara pendokumenan dan dengan cara pengamatan suatu objek. Bentuk dokumentasi dalam penelitian ini adalah untuk mengumpulkan data yang merupakan kumpulan opini dalam koran Radar Banten edisi November-Desember 2016. Adapun langkah-langkah yang dilakukan dalam mengumpulkan data-data adalah sebagai berikut :

1. Membaca berulang-ulang untuk memahami teks opini dalam koran Radar Banten edisi November-Desember 2016 sehingga dapat mengapresiasikan sumber data tersebut dan mencatat hal-hal yang akan dianalisis yang berhubungan dengan apa yang akan diteliti

2. Membaca dan mempelajari literatur, referensi atau bahan pustaka yang mempunyai hubungan dan menunjang terhadap persoalan dan permasalahan dalam penelitian ini, mencatat hal-hal penting yang diharapkan agar menemukan kajian-kajian yang relevan serta berkesinambungan dengan teks opini yang dipilih yang sesuai dengan permasalahan sehingga mampu melahirkan suatu jawaban berupa bentuk campur kode dari kumpulan teks opini yang dikaji.

3. Mencatat dan memasukkan data yang diperoleh dari rubrik opini koran Radar Banten edisi November-Desember 2016 ke dalam instrumen analisis data .

4. Menganalisis dan mendeskripsikan data yang diperoleh dari rubrik opini koran Radar Banten edisi November-Desember 2016.

5. Memberi kesimpulan dari hasil analisis data sesuai dengan fokus penelitian, rumusan masalah, dan tujuan penelitian. 
Analisis data dalam penelitian ini dilakukan pada saat pengumpulan data berlangsung dan setelah selesai pengumpulan data. Analisis data dalam penelitian ini diperoleh dari berbagai sumber, dengan menggunakan teknik pengumpulan data yang bermacam-macam, dan dilakukan secara terus menerus sampai datanya penuh. Aktivitas dalam analisis data tersebut adalah reduksi data, penyajian data dan menarik kesimpulan data:

1. Reduksi Data

Mereduksi data yaitu memfokuskan diri pada data yang dibutuhkan sesuai kriteria yang telah ditentukan. Pada langkah ini peneliti memilih data-data yang pokok atau halhal yang penting. Data-data yang dipilih hanya data yang berkaitan dengan masalah yang akan dianalisis. Dalam penelitian ini data-data yang dipilih tentang campur kode dalam rubrik opini koran Radar Banten edisi November-Desember 2016.

\section{Penyajian Data}

Setelah dilakukan pereduksian data, selanjutnya dilakukan penyajian data. Pada langkah ini, data disajikan dengan menyiapkan tabel bentuk-bentuk campur kode.

\section{Menarik Kesimpulan}

Kesimpulan awal yang dikemukakan masih bersifat sementara, dan akan berubah bila tidak ditemukan bukti-bukti yang kuat yang mendukung pada tahap pengumpulan data berikutnya. Akan tetapi, apabila kesimpulan yang dikemukakan pada tahap awal, didukung oleh bukti-bukti yang valid dan konsisten saat peneliti kembali ke lapangan untuk mengumpulkan data, maka kesimpulan yang dikemukakan merupakan kesimpulan yang kredibel.

\section{Pembahasan}

Pada bagian ini, penulis akan membahas temuan hasil penelitian tentang campur kode pada rubrik opini koran Radar Banten edisi November-Desember 2016, yang akan dijabarkan sebagai berikut :

Dia layak disebut sebagai karyawan teladan yang memiliki jiwa ownership lantaran kesanggupannya menabrak SOP di perusahaan tempatnya bekerja.

Pada kutipan di atas terdapat peristiwa campur kode dalam bentuk kata. Dengan adanya kata "ownership" yang berasal dari bahasa Inggris yang berarti "kepemilikan”. Dalam kutipan tersebut terdapat peristiwa campur kode karena campur kode akan terjadi apabila di dalam 
peristiwa tutur terdapat campuran unsur-unsur bahasa yang berbeda dengan bahasa yang sedang digunakan.

Maka, diapun telah masuk ke dalam suatu pilihan, mau diikuti atau cabut dari habitat yang sedang kadung di dalamnya.

Pada kutipan di atas terdapat peristiwa campur kode dalam bentuk kata. Dengan adanya kata "kadung” yang berasal dari bahasa Jawa yang berarti "terlanjur" Dalam kutipan tersebut terdapat peristiwa campur kode karena campur kode akan terjadi apabila di dalam peristiwa tutur terdapat campuran unsur-unsur bahasa yang berbeda dengan bahasa yang sedang digunakan.

Sambil memakai bon pembelian, dia pun mengajukan reimburse ke perusahaan milik negara lain.

Pada kutipan di atas terdapat peristiwa campur kode dalam bentuk kata. Dengan adanya kata "reimburse" yang berasal dari bahasa Inggris yang berarti "mengembalikan". Dalam kutipan tersebut terdapat peristiwa campur kode karena campur kode akan terjadi apabila di dalam peristiwa tutur terdapat campuran unsur-unsur bahasa yang berbeda dengan bahasa yang sedang digunakan.

Hendaknya bersikap fair dan rendah hati.

Pada kutipan di atas terdapat peristiwa campur kode dalam bentuk kata. Dengan adanya kata "fair" yang berasal dari bahasa Inggris yang berarti “adil, wajar”. Dalam kutipan tersebut terdapat peristiwa campur kode karena campur kode akan terjadi apabila di dalam peristiwa tutur terdapat campuran unsur-unsur bahasa yang berbeda dengan bahasa yang sedang digunakan.

Di sekolah itu, kata-kata guru, terlebih kepala sekolah, adalah fatwa atau barangkali sabda yang mesti dipatuhi, dilaksanakan.

Pada kutipan di atas terdapat peristiwa campur kode dalam bentuk kata. Dengan adanya kata "fatwa" yang berasal dari bahasa Arab yang berarti "nasehat, petuah, atau pendapat". Dalam kutipan tersebut terdapat peristiwa campur kode karena campur kode akan terjadi apabila 
di dalam peristiwa tutur terdapat campuran unsur-unsur bahasa yang berbeda dengan bahasa yang sedang digunakan.

Di sekolah itu, kata-kata guru, terlebih kepala sekolah, adalah fatwa atau barangkali sabda yang mesti dipatuhi, dilaksanakan.

Pada kutipan di atas terdapat peristiwa campur kode dalam bentuk kata. Dengan adanya kata "sabda" yang berasal dari bahasa Arab yang berarti "perkataan". Dalam kutipan tersebut terdapat peristiwa campur kode karena campur kode akan terjadi apabila di dalam peristiwa tutur terdapat campuran unsur-unsur bahasa yang berbeda dengan bahasa yang sedang digunakan.

Para siswa, dalam film itu, mencari sendiri bakat dan passion mereka.

Pada kutipan di atas terdapat peristiwa campur kode dalam bentuk kata. Dengan adanya kata "passion" yang berasal dari bahasa Inggris yang berarti "gairah”. Dalam kutipan tersebut terdapat peristiwa campur kode karena campur kode akan terjadi apabila di dalam peristiwa tutur terdapat campuran unsur-unsur bahasa yang berbeda dengan bahasa yang sedang digunakan.

Dalam bahasa ekstrimnya bahwa masyarakat Banten belum melek informasi pilkada dan calon pemimpin belum masuk ke ruang-ruang terdekat dalam dirinya.

Pada kutipan di atas terdapat peristiwa campur kode dalam bentuk kata. Dengan adanya kata "melek" yang berasal dari bahasa Betawi yang berarti "sadar". Dalam kutipan tersebut terdapat peristiwa campur kode karena campur kode akan terjadi apabila di dalam peristiwa tutur terdapat campuran unsur-unsur bahasa yang berbeda dengan bahasa yang sedang digunakan.

Pada sisi lain, program yang ditawarkan calon sangat tidak menarik dan hanya bersifat retorika dan lips service yang bersifat sementara.

Pada kutipan di atas terdapat peristiwa campur kode dalam bentuk frase verbal. Dengan adanya frase "lips service" yang berasal dari bahasa Inggris yang berarti "layanan bibir". Dalam kutipan tersebut terdapat peristiwa campur kode karena campur kode akan terjadi apabila di dalam peristiwa tutur terdapat campuran unsur-unsur bahasa yang berbeda dengan bahasa yang sedang digunakan. 
Sistem pembiayaan private, ditetapkan oleh pasar termasuk asuransi swasta.

Pada kutipan di atas terdapat peristiwa campur kode dalam bentuk kata. Dengan adanya kata "private"yang berasal dari bahasa Inggris yang berarti "pribadi". Dalam kutipan tersebut terdapat peristiwa campur kode karena campur kode akan terjadi apabila di dalam peristiwa tutur terdapat campuran unsur-unsur bahasa yang berbeda dengan bahasa yang sedang digunakan.

Sistem pelayanan kesehatan berubah, budgeting pemerintah berubah.

Pada kutipan di atas terdapat peristiwa campur kode dalam bentuk kata. Dengan adanya kata "budgeting"yang berasal dari bahasa Inggris yang berarti "penganggaran". Dalam kutipan tersebut terdapat peristiwa campur kode karena campur kode akan terjadi apabila di dalam peristiwa tutur terdapat campuran unsur-unsur bahasa yang berbeda dengan bahasa yang sedang digunakan.

Berdasarkan data targer road map Badan Penyelenggara Jaminan Sosial (BPJS) 2014-2016.

Pada kutipan di atas terdapat peristiwa campur kode dalam bentuk frase nomina. Dengan adanya frase "road map" yang berasal dari bahasa Inggris yang berarti "peta jalan". Dalam kutipan tersebut terdapat peristiwa campur kode karena campur kode akan terjadi apabila di dalam peristiwa tutur terdapat campuran unsur-unsur bahasa yang berbeda dengan bahasa yang sedang digunakan.

Kelompok masyarakat ini sebagai bentuk kekuatan civil society di Provinsi Banten.

Pada kutipan di atas terdapat peristiwa campur kode dalam bentuk frase nomina. Dengan adanya frase "civil society" yang berasal dari bahasa Inggris yang berarti "masyarakat sipil". Dalam kutipan tersebut terdapat peristiwa campur kode karena campur kode akan terjadi apabila di dalam peristiwa tutur terdapat campuran unsur-unsur bahasa yang berbeda dengan bahasa yang sedang digunakan. 
Dengan keikutsertaan masyarakat dalam Focus Group Discussion tentang pembangunan yang difasilitasi oleh humas pemerintah.

Pada kutipan di atas terdapat peristiwa campur kode dalam bentuk klausa. Dengan adanya klausa "Focus Group Discussion" yang berasal dari bahasa Inggris yang berarti "Kelompok Fokus Diskusi”. Dalam kutipan tersebut terdapat peristiwa campur kode karena campur kode akan terjadi apabila di dalam peristiwa tutur terdapat campuran unsur-unsur bahasa yang berbeda dengan bahasa yang sedang digunakan.

\section{Wallahu'alam bish showab}

Pada kutipan di atas terdapat peristiwa campur kode dalam bentuk klausa. Dengan adanya klausa "Wallahu'alam bish showab" yang berasal dari bahasa Arab yang berarti "Dan Allah lebih mengetahui yang sebenar-benarnya”. Dalam kutipan tersebut terdapat peristiwa campur kode karena campur kode akan terjadi apabila di dalam peristiwa tutur terdapat campuran unsurunsur bahasa yang berbeda dengan bahasa yang sedang digunakan.

Wajar jika penguatan supremasi hokum dan kelembagaannya menjadi pusat perhatian founding father Indonesia.

Pada kutipan di atas terdapat peristiwa campur kode dalam bentuk frase nomina. Dengan adanya frase "founding father" yang berasal dari bahasa Inggris yang berarti "bapak pendiri". Dalam kutipan tersebut terdapat peristiwa campur kode karena campur kode akan terjadi apabila di dalam peristiwa tutur terdapat campuran unsur-unsur bahasa yang berbeda dengan bahasa yang sedang digunakan.

Sebut saja program tax amnesty yang menuai kesuksesan besar.

Pada kutipan di atas terdapat peristiwa campur kode dalam bentuk frase nomina. Dengan adanya frase "tax amnesty" yang berasal dari bahasa Inggris yang berarti "pengampunan pajak". Dalam kutipan tersebut terdapat peristiwa campur kode karena campur kode akan terjadi apabila di dalam peristiwa tutur terdapat campuran unsur-unsur bahasa yang berbeda dengan bahasa yang sedang digunakan. 
Presiden.

Publik masih ingat bahwa Ignasius adalah salah satu mentri yang direshuffle oleh

Pada kutipan di atas terdapat peristiwa campur kode dalam bentuk kata. Dengan adanya kata "reshuffle" yang berasal dari bahasa Inggris yang berarti "perombakan". Dalam kutipan tersebut terdapat peristiwa campur kode karena campur kode akan terjadi apabila di dalam peristiwa tutur terdapat campuran unsur-unsur bahasa yang berbeda dengan bahasa yang sedang digunakan.

Segala penafsiran apapun dari manusia yang coba-coba punya interpretasi tentang kitab suci adalah bathil dan bid'ah.

Pada kutipan di atas terdapat peristiwa campur kode dalam bentuk kata. Dengan adanya kata "bathil" yang berasal dari bahasa Arab yang berarti “rusak, salah, palsu”. Dalam kutipan tersebut terdapat peristiwa campur kode karena campur kode akan terjadi apabila di dalam peristiwa tutur terdapat campuran unsur-unsur bahasa yang berbeda dengan bahasa yang sedang digunakan.

Segala penafsiran apapun dari manusia yang coba-coba punya interpretasi tentang kitab suci adalah bathil dan bid'ah.

Pada kutipan di atas terdapat peristiwa campur kode dalam bentuk kata. Dengan adanya kata "bid'ah" yang berasal dari bahasa Arab yang berarti "pembaruan, doktrin sesat". Dalam kutipan tersebut terdapat peristiwa campur kode karena campur kode akan terjadi apabila di dalam peristiwa tutur terdapat campuran unsur-unsur bahasa yang berbeda dengan bahasa yang sedang digunakan.

\section{E. Simpulan}

Berdasarkan hasil analisis tentang campur kode dalam rubrik opini koran Radar Banten edisi November-Desember 2016, penulis menyimpulkan bentuk campur kode yang ditemukan dalam rubrik opini koran Radar Banten edisi November-Desember 2016 sebanyak 5 bentuk, antara lain : campur kode berbentuk kata, campur kode berbentuk frase, campur kode berbentuk baster, campur kode berbentuk klausa, dan campur kode berbentuk 
ungkapan. Adapun jumlah data masing-masing bentuk campur kode tersebut adalah sebagai berikut :

1. Campur kode berbentuk kata sebanyak 30 data, dengan 13 campur kode dalam bahasa Inggris, 11 campur kode dalam bahasa Arab, 3 campur kode dengan bahasa Jawa, dan 3 campur kode dengan bahasa Betawi.

2. Campur kode berbentuk frase sebanyak 13 data, dengan 9 campur kode berbentuk frase nomina dalam bahasa Inggris, dan 4 campur kode berbentuk frase verbal dalam bahasa Inggris.

3. Campur kode berbentuk baster sebanyak 3 data, dengan 2 campur kode dalam bahasa Arab, dan 1 campur dalam bahasa Inggris.

4. Campur kode berbentuk klausa sebanyak 2 data, dengan 1 campur kode dalam bahasa Inggris, dan 1 campur kode dalam bahasa Arab.

5. Campur kode berbentuk ungkapan sebanyak 1 data dalam bahasa Arab.

Jumlah data keseluruhan dari hasil penelitian ini berjumlah 49 data. Secara

keseluruhan, campur kode bahasa Inggris ke dalam bahasa Indonesia lebih dominan dibandingkan dengan campur kode bahasa Arab, campur kode bahasa betawi, dan campur kode bahasa Jawa.

\section{Daftar Pustaka}

Aslinda dan Leni Syafyahya. 2014. Pengantar Sosiolinguistik. Bandung : Refika Aditama.

Chaer Abdul dan Leonie Agustina. 2010. Sosiolinguistik Perkenalan Awal. Jakarta : Rineka Cipta.

Olii, Helena \& Erlita. 2011. Opini Publik. Jakarta : Indeks.

Suwito. 1983. Pengantar Awal Sosiliolinguistik Teori dan Problema. Surakarta : Fakultas Sastra Universitas Sebelas Maret. 